\title{
Private providers and market exit in UK higher education
}

\section{Stephen A. Hunt ${ }^{1}$ (D) $\cdot$ Vikki Boliver $^{2}$ (D)}

Published online: 19May 2020

(C) The Author(s) 2020

\begin{abstract}
The sudden closure of higher education providers is virtually unknown among publicly funded higher education institutions in the UK, but "market exit" is commonplace among private higher education providers. The UK government is actively championing the expansion of private higher education providers despite a dearth of research on the factors associated with a heightened risk of market exit within this part of the UK higher education sector. We set out to fill this gap in knowledge by utilizing existing data on private higher education providers active in the UK in 2014 supplemented by newly collected data on the status of these providers in 2019. The likelihood of market exit was higher for more recently founded providers, those operating for profit, those specializing in Business or IT or else having no particular specialization, and those located in London-all features that represent areas of greatest competition in the private higher education sector. Further risk factors associated with an increased likelihood of market exit were no external quality assessment, no access to publicly backed tuition fee loans, and the removal of the legal right to recruit international students. This second set of risk factors suggest that it is not just denial of revenue streams that increases the likelihood of market exit but estrangement from an officially regulated higher education system.
\end{abstract}

Keywords UK·Privatehighereducation · Market exit - Insolvency $\cdot$ Bankruptcy $\cdot$ Business closure

Stephen A. Hunt

stephen.hunt@ucl.ac.uk

Vikki Boliver

vikki.boliver@durham.ac.uk

Extended author information available on the last page of the article 


\section{Introduction}

Publicly funded higher education (HE) institutions in the UK have historically enjoyed protection from government against sudden closure. Private providers, operating in an unregulated market, in contrast, have always been unprotected and market exit, bankruptcy or voluntary closure, is commonplace. ${ }^{1}$ The evidence indicates that, in an unregulated market, exit becomes standard. Examining private providers, Hunt and Boliver (2019) found that, of the 732 private HE providers identified as operating in the UK in 2014 (Shury et al., 2016), 198 had ceased to operate by 2019, their market exit a matter of record in their Companies House entry, or evident from abandoned websites. These represent $27 \%$ of the total 2014 population of private providers.

Market exit is cited as a regulatory mechanism for removing substandard providers and thereby improving the sector generally (BIS 2016). Yet the closure of institutions, and particularly their sudden exit, has several serious consequences. At the very least, it involves interruptions to students' courses, and a period negotiating their transfer to another provider, if possible; where it is not, students face the prospect of incomplete courses, with the associated sunk costs of time and money. The mere threat of closure itself can destabilize the sector, disincentivizing students to enrol in institutions perceived as being at risk, thereby increasing the probability that such institutions will ultimately fail. Closure itself reduces the HE sector in terms of capacity, and potentially geographic spread, which is particularly problematic if closures occur in areas with already limited provision or affects institutions with rarer forms of specialist provision.

Market exit indicates a distinction between public and private providers profound enough to render the two sectors difficult to reconcile. Furthermore, both sectors have developed under distinct regulatory regimes. Scott's (2010) institutional field approach allows the private sector to be integrated within an organizational structure applicable to the UK higher education generally. The separation between, in this case, the public and private sectors, is acknowledged and accounted for in terms of differing institutional logics (March and Olsen 1989). Logics refer to the cognitive frameworks or "the belief systems and associated practices that operate in an organizational field" (Scott 2010, p.24). Logics serve to guide the conduct of the social actors located in an institutional field, although complex fields can contain multiple logics.

Actors in the public sector, at least ideally, embrace a logic of appropriateness, "stressing adherence to the rules and requirements of the larger epistemic community and one's role in perpetuating it" (Scott 2010, p.27). Yet such a logic has, latterly, been compromised by a willingness to bend to market forces, as explored below. Conversely, the private sector, specifically the for-profit element, has embraced instrumental logic, of undiluted market forces, characterized by "stressing the value of self-interest and attention to cost-benefit criteria in making choices" (Scott 2010, p.28).

The absence of a comprehensive regulatory regime means there has never been a reliable official inventory of private HE providers operating in the UK. Consequently, incidences of market exit tend to go unobserved. Other than what can be gleaned from the few high profile cases, little is known about its prevalence or causes.

\footnotetext{
${ }^{1}$ Private higher education institutions are defined as those that do not receive direct recurring government funding. Private schools concerned with compulsory education that are not funded by the state but charge fees are, in the UK, confusingly, referred to as "public schools". The term derives from the fact that the Public Schools Act 1868 gave seven long established schools independence from direct jurisdiction or responsibility of the Crown, the established church, or the government.
} 
Despite this opacity, the current UK government is keen to see the private HE sector expand substantially (BIS 2016). More private providers are equated with greater competition. A corollary of this is a greater likelihood of market exit, not only among private providers but also within the publicly funded sector.

This paper sets out to identify the risk factors associated with an increased likelihood of market exit among private HE providers in the UK as the predictors of market exit remain obscure. We do so by drawing on data collected in 2019 on private HE providers identified in a previous study conducted in 2014, distinguishing between those that are no longer in operation and those that are still active.

The research is focused on the UK but has application more widely, particularly in countries with a significant private HE sector. These include nations as diverse as Japan (Mizobata and Yoshii 2015) and Chile (Bernasconi 2007) where around three quarters of HE students are enrolled in private institutions. It also extends to countries with smaller private HE sectors but where high levels of instability are apparent: these include the USA where a series of for-profit multi-state providers along with smaller concerns have folded (Angulo 2016), and Poland (Kwiek 2013, 2016) where a declining demographic has seen a shrinking private HE sector.

\section{Marketization and market exit}

The marketization of UK higher education that began in the late 1970s rests on the assumption reiterated in the 2016 White Paper, Success as a Knowledge Economy, that:

Competition between providers in any market incentivises them to raise their game, offering consumers a greater choice of more innovative and better quality products and services at lower cost. Higher education is no exception. (BIS 2016, p. 8)

The expectations associated with the introduction or intensification of competition can be traced back to Milton Friedman's The Role of Government in Education (1955), where market competition is held as maximizing efficiency, responsiveness, and innovation (Marginson 2013; McGettigan 2013).

The process of marketization was initiated in the UK with a series of funding reductions to higher education that took place from 1979 onwards (Williams 1992, 1997). The Universities' response to these cuts was to seek new sources of revenue or increase existing ones, for example, by increasing foreign student enrolments or reducing costs. Marketization progressed through the 1980s and 1990s principally through the application of the organizational practices of New Public Management (NPM) (Ferlie et al. 1996; Ferlie et al. 2008; Naidoo 2007). The application of NPM across the public sector has become standard; its approach characterized in terms of marketization, modernization, and minimization (Shattock 2008):

In higher education, the NPM is associated with reforms that render institutions as quasibusiness firms (corporatisation), including CEO-style executive leadership; goal-driven production, output measurement and performance management; cost unbundling, shadow pricing and simulated 'bottom lines' in non revenue areas; customer focus and continuous self-evaluation. (Marginson 2013, p. 355)

Latterly the public higher education sector has been driven from a quasi-market realized via NPM to a state closer to that of full economic commercialization through a series of staggered reforms principally concerning the introduction of tuition fee loans and the removal of number 
caps on student recruitment (Hillman 2014; Palfreyman and Tapper 2016). These reforms have meant public providers are now compelled to compete with each other for student enrolment to fund any expansion or even to maintain their presence.

The competition envisaged in Success as a Knowledge Economy was not simply between existing providers, but between incumbents and "[n] ew and innovative providers offering high quality higher education" (BIS 2016, p 9, para 11). These new providers were not to be creations of the state, but private providers.

The government policy in Success as a Knowledge Economy involved private investment in higher education as a means of addressing a perceived lack of innovation and deficient rates of return (in terms of later earnings) identified with some degree programmes. This narrow concentration on private returns, a type of "methodological individualism" (Infantino 1998), while coherent, fails to acknowledge the well-documented association between public investment in higher education and less tangible, more diffuse societal returns and public goods. The former include increased tax revenues and decreased reliance on social welfare programmes; the latter, universal knowledge and information (Blagg and Blom 2018; Marginson 2011).

The principle reforms in Success as a Knowledge Economy directed at private providers were the removal of barriers to entry and expansion. Private providers had already been granted licence to enrol students with government-backed tuition fee loans on specifically approved "designated courses", academic programmes of study leading to particular qualifications, ranging from sub-bachelor certificates and diplomas to postgraduate degrees.

Consequently, removing the remaining barriers amounted to making it easier to acquire legally protected titles, University and University College, and degree awarding powers. Private providers had lobbied against these barriers to entry and expansion as unfair restrictions that tilted the playing field in favour of incumbents (Stockwell 2016). A commitment to their removal was duly incorporated into Success as a Knowledge Economy and subsequently realized in the Higher Education and Research Act 2017 (H.M. Government 2017).

Together with competition between autonomous suppliers, freedom to set prices that cover costs and that fall on the consumer, information to allow consumers to make rationale choices between providers, and opportunities for market entry, market exit has been identified as a key component of a fully marketized system of higher education (Brown 2008; Jongbloed 2004). Success as a Knowledge Economy makes clear that while increased competition was expected to realize a series of specific positive outcomes, the corollary was that competition could lead to market exit.

This represents a clear break with the official response to struggling providers historically: no publicly funded HE provider has exited the market until recently, despite several close calls. University College Cardiff faced bankruptcy in the mid-1980s (Shattock 1988; Smith and Cunningham 2003). Lancaster University reached the brink of financial collapse in 1996 (Deem 1998; McClintock and Ritchie 2003). London Metropolitan University (LMU), in the mid-2000s, was found to have misreported its student numbers to HEFCE, prompting HEFCE to reclaim $£ 36.5$ million in funding for the period 2005-2008 and to reduce LMU's recurrent teaching funding by $£ 15$ million annually from 2008/2009 onwards, resulting in significant financial difficulties (Newman 2009). Subsequently, in 2012, LMU had its Tier 4 licence to recruit international students from outside the European Economic Area (EEA) or Switzerland removed, again threatening a valuable income stream; it was, at that point, serving a total cohort of 10,000 international students (EU and non-EU), 10\% of London's total (Thomas 2012). HEFCE acted on both occasions to keep LMU functioning (Evans 2018). 
However, both HEFCE and the interventionist role it played have since disappeared. HEFCE was replaced by the Office for Students (OfS) in 2018, and its mission to rescue failing institutions replaced by a determination to promote market exit, using the mechanisms of competition to drive out inadequate or failing providers. The OfS did make a near $£ 1$ million bridging loan to keep a struggling but unidentified university afloat in 2018, but this was a legacy of HEFCE's role, "promised under the transition rules" (Vaughan 2018).

The closure of Heythrop College in 2018 was the first incident of a major UK public provider exiting the market since 1265 . Heythrop, a specialist in theology and philosophy, was a constituent college of the University of London. Its exit was attributed to the increase in the tuition fee ceiling to $£ 9000$ and a consequent reduction in enrolments (Grove 2018). Public providers facing a fall in enrolments seldom experience institutional collapse. Usually, being elements in a common system of higher education, there is the opportunity for merger. According to HESA sources, between 1995/1996 and 2016/2017, there were 49 higher education institution mergers in the UK (35 in England) (Ferlie and Trenholm 2018). A merger was tabled for Heythrop but never pursued.

\section{Market exit in the private sector}

Merger is a less likely option for privately owned institutions, not part of a common system, nor has there been any regulatory body equivalent to HEFCE to step in to rescue a failing institution. It is perhaps unsurprising then that the near absence of institutional failure in the public sector is not mirrored in the private HE sector. Despite the high incidence of market exit among private HE providers, these closures have gone largely unobserved, only occasionally becoming visible when the threat to public finances or the education of students is sufficiently large to warrant media coverage.

The issue of market exit although rarely featuring in accounts of higher education is commonplace in industrial dynamics, economics, and business research, the simple survival of a firm being taken as an indicator of entrepreneurial success (Santarelli and Vivarelli 2007). Market exit is not entirely reducible to involuntary liquidation: it can also be the result of the voluntary decision to terminate or otherwise abandon a business (Taylor 1999). This distinction can be seen in the UK higher education sector, with clearly differing consequences for students. Kaplan Inc., for instance, announced the discontinuation of Kaplan Law School in 2015 (Coyne 2015). Courses were closed to new students, and the existing courses taught out with the institution closing in 2018. The London College of Contemporary Music (LCCM), in contrast, was tipped precipitously into receivership in January 2017, and immediately ceased teaching (Boyd and Kernohan 2018); we consider the consequences for students at LCCM in more detail below.

Private providers also face particularly acute pressures associated with generating income from student enrolment, heightening their risk of market exit. Two critical sources of tuition fee income that are often less accessible and more difficult to maintain for private than for public providers are fee income from "designated courses" for which students are permitted to access government-backed tuition fee loans and fee income from the recruitment of international students (defined as those from outside the EEA or Switzerland) who can be charged much higher tuition fees. We examine these and further factors likely to influence sustainability in the following sections. 
a) Course designation

Publicly funded higher education providers in England are automatically entitled to enrol students who finance their tuition fees using government-backed student loans. Private providers, in contrast, must apply to have their courses "designated" for student loan funding. ${ }^{2}$ Despite the difficulties of obtaining course designation, access to public funds provides a default-free revenue stream. Consequently, failure to obtain course designation or subsequent removal of course designation represents a significant risk factor in relation to market exit.

The government, from 2011, extended the right to enrol students with access to government-backed tuition fee loans to about 140 "alternative providers" to use the governments' preferred terminology, or more precisely private providers, those not in receipt of direct recurring state funding, and removed restrictions on the number of such students a provider could recruit, as a means of encouraging growth in the private higher education sector. However, the size of the tuition fee loan available to private providers was limited to $£ 6000$ per annum, far lower than the maximum tuition fee loan available for courses in publicly funded providers of $£ 9000$. $^{3}$

Despite this comparative underfunding, the growth in private provider student recruitment initiated in 2010/2011 with the lifting of restrictions on recruitment for designated courses exceeded expectations. Students claiming government-backed financial support for courses at private providers rose from 7000 to 53,000 between 2010/11 and 2013/2014. Over the same period, the amount paid to students at private providers in grants and loans rose from $£ 50$ million to $£ 675$ million (Public Accounts Committee 2015), and to as much as $£ 724$ million according to a later estimate (National Audit Office 2017). Alarmed, the government sought to put the brakes on the expansion.

Following a restriction on recruitment in 2014/2015, further student number controls were introduced. Total student support paid in $2014 / 2015$ had fallen to $£ 417$ million (National Audit Office 2017). The restriction on recruitment in the alternative sector occurred just as number caps were first relaxed, then removed in 2015-2016 in the public sector in England.

All alternative providers enrolling publicly funded students are obliged to have "student protection plans", a form of indemnity against market exit (BIS 2016, p.38, para 34). Where the provider has a validating institution, it is the validating body's responsibility to have drawn up such a plan. Yet even in the private sector, student protection plans have seldom been triggered. LCCM provides an example where one has.

A financial statement from 2016 including the results of an independent audit makes it clear that the management was seeking to financially restructure LCCM and that without this occurring the company was facing financial risk.

Yet its collapse in 2018 was unexpected: HEFCE only became aware of LCCM being placed into administration the working day before it happened (Boyd and Kernohan 2018). Nevertheless the student protection plan was swiftly activated. The LCCM's validating body, the Open University, began to take steps to relocate students to the Academy of Contemporary Music (ACM), a well-established alternative provider in London, but this was quickly halted:

\footnotetext{
${ }^{2}$ Prior to 2016, private providers needed to apply to the Department for Business Innovation and Skills (BIS); between 2016 and March 2018, it was the Department for Education; from April 2018, the responsibility shifted to the Office for Students.

${ }^{3}$ Unlike public providers, private providers' tuition fees were not capped; however, the $£ 6000$ (or $£ 6165$ if the provider has achieved a Teaching Excellence Framework rating of "Meets Expectations in Year One") ceiling on the loan effectively served as a tuition fee cap in many instances.
} 
on the 12th of January, LCCM was bought by Au Bidco Ltd. (a wholly owned subsidiary of Global University Systems BV). A consequence of the sale meant students could continue their studies (Boyd and Kernohan 2018; O'Reilly and Thomas 2018).

Financial instability is not limited to small-scale or marginal providers. GSM London, at one stage the largest private provider in the UK enrolling over 8000 students a year, made a loss of $£ 9.9$ million in 2017 , and $£ 26$ million of debt was waived by its private equity owners (Morgan 2018). GSM announced its cessation of higher education provision in July 2019 and that it would stop teaching at the end of September 2019 (Morgan 2019). In the wake of the closure, the OfS refused to recognize GSM's student protection plan, consequently relocation of its students was conducted in accord with the University of Plymouth's plan, GSM's validating institution. A significant number of GSM's students were offered the opportunity to transition onto courses at Coventry University Group's London campuses (Coventry University Group 2019; Morton 2019).

\section{b) Removal of Tier 4 licences}

Fielden (2010) identified an area of rapid growth in the private higher education sector as "small private colleges targeting international students and accredited by UK universities to offer their awards". Fielden observes that "the number of non-EU international students at these institutions is unknown, but it is growing" (Fielden 2010, p.5), and noted that even at that point a reduction in the number of Tier 4 licences was underway involving the UK Border Agency, the British Accreditation Council, and the Accreditation Service for International Colleges.

Recruitment of international students depends on obtaining a Tier 4 visa licence to sponsor international students. There was a sustained campaign to remove Tier 4 status from a large number of institutions in the tertiary education sector from 2010 onwards, with private providers heavily targeted. The removal of Tier 4 status approval was not an act of closure in itself, but negotiating a financially viable existence after being denied access to a key market may have been beyond many providers. Nor was the removal of Tier 4 sponsor status undertaken for educational considerations, but rather as a means of exercising (partial) control over immigration numbers.

The underlying assumption was that any international student was an illegal immigrant in potentia: having gained entrance to the country such students could simply vanish into the black economy, the tertiary education provider acting as a portal (May 2011).

Government figures covering the period May 2010 to October 2014 indicated that 836 providers had had their Tier 4 Sponsorship licences removed (GOV.UK 2014).

Removal of Tier 4 licences presents a clear risk to providers, and a risk that, for the private sector, has been compounded with the intensification of government efforts to reduce the prevalence of Tier 4 licences in the tertiary education sector.

c) The Quality Assurance Agency (QAA) review

The QAA for higher education works throughout the UK, "monitoring and advising on standards and quality in UK higher education" (QAA 2019). The restructuring of English higher education initiated with Success as a Knowledge Economy (2017) effectively made the QAA instrumental in the approval process for the registration of both current and new providers with the OfS. Central to this are the QAA reviews and monitoring engagements 
of providers. The review for an alternative provider involves two stages: an information assessment and a physical visit. Independent of the review method, an institution's financial sustainability, management, and governance are also scrutinized (QAA 2017). The period 2017/2018 saw 60 reviews of alternative providers, and 121 monitoring engagements.

A review estimates whether the quality of and information about learning opportunities and enhancement of student learning opportunities meets UK expectations, as articulated in the UK Quality Code for Higher Education (QAA 2018). A QAA review has also been a necessary condition for course designation, but is not restricted to institutions with course designation. Three characteristics have been associated with an increased likelihood of a poor or failed review: smaller and newer alternative providers operating without validating arrangements (Havergal 2016). Yet the proportion of alternative or private providers subject to a review is quite small: only around $20 \%$. Furthermore, if a review identifies deficiencies, areas that fail to meet expectations, the provider will receive advice on improvements and the opportunity for a second review. Private providers, then, are unlikely to have been subject to a QAA review, and, of those that receive poor reviews, many do not face direct consequences; although, ultimately, poor reviews can provide grounds from removing course designation. QAA reviews represent a minimized risk to providers but are also indicative of a provider positioned in a general system of oversight. We consider whether a review with its potential for a poor outcome is of greater consequence than an absence of any external assessment for a provider's longevity.

d) Additional market exit factors.

Data available from 2017 indicated that private for-profit providers represent the most volatile element of the private sector: private limited companies, i.e. for-profit institutions accounted for $61 \%$ of all private providers identified in 2014 but $90 \%$ of those that had failed by 2017 (Hunt and Boliver 2019).

Other measures relevant to market exit that feature in the present research include age of institution, location, and size of enrolment. There is evidence that smaller and younger enterprises are more vulnerable to market exit than the larger and more established and that the incidence of market exit generally is greater in the capital (Nilsson 2017). All three factors are apparent in the case of the New College of Humanities (NCH). Less than 10 years old, $\mathrm{NCH}$ was founded in London in 2012. It was identified as an exemplar of the kind of private provider the government was keen to see enter the market, undergraduate provision based around Oxbridge style tutorial groups. Yet it was operating at a loss, with student numbers of around 200 insufficient to meet all of the costs of the college, and had been relying on a shareholder loan. NCH has not exited the market but was recently bought out, merged, or, to quote the college's master A.C. Grayling "is entering into a global strategic partnership" with a US college Northeastern (Grayling 2018).

Subjects taught also have a possible link to market exit. It is likely that the high prevalence of business and administrative studies courses offered within the private HE sector increases the likelihood of market exit for providers that exclusively or predominantly offer these subjects, simply on the basis of greater competition. Hunt and Boliver (2019) identified over $55 \%$ of all private providers in the UK offered at least one business/administrative course, the subject with by far the greatest prevalence.

Based on the forgoing, we identify for-profit status as a likely predictor of market exit, that is, for-profit institutions are more likely to fail than not-for-profits. Furthermore, we also predict that providers' location, specifically location in the capital, those of smaller size, and those more recently established are all more likely to experience market exit. Additionally, 
given the density of the marketplace, those providers offering business and administration are more likely to exit the market.

\section{Data and methods}

The research involves the analysis of secondary data sources supplemented with new information collected by the research team in 2019. Our principle source of secondary data is a UKwide survey of alternative higher education provision commissioned by the Department of Business Innovation and Skills (BIS) in 2014. The survey identified 732 alternative providers. Elementary data was collected on the whole population, including information on the following: institutional subject specialism, if applicable; number of students; location, based on the postcode of the providers' main site; course (or institutional) designation, enabling eligible students to access government-backed tuition fee loans; and removal or suspension (hereafter removal) of a Tier 4 licence to recruit international students (Shury et al. 2016).

We supplemented these data with information we collected for each provider from their website, Companies House records and/or the charities register, ${ }^{4}$ and from Quality Assurance Agency reports. The additional information collected included the following: the legal structure of the company (e.g. private limited company); foundation date; whether or not the provider had undergone a QAA review; and whether or not the provider had closed by 2019 as indicated by Companies House records or by the provider no longer having a web presence.

Although 732 alternative providers' were identified as active in 2014, our analytical sample is restricted to 564 of these. This is because our 2019 data collection exercise revealed that 33 of the providers identified in 2014 were not in fact private providers (e.g. were military or National Health Service organizations or further education colleges), 125 were active but no longer providing HE, 7 were duplicated entries in the original list, and three lacked sufficient data.

Over the period 2014-2019, a total 198 providers were found to have exited the private HE market, $27 \%$ of the 2014 total, or $35 \%$ of the 564 private providers in our analytical sample. We explore the predictors of market exit below, beginning by presenting a descriptive account of provider characteristics and their bivariate relationship to market exit rates. We then report the results of a multivariate analysis with market exit as the dependent variable in a binary logistic regression model.

\section{Results}

As Table 1 shows, there is a great prevalence of market exit among for-profit institutions and among younger providers. Provider size does not appear to be strongly associated with market exit, although this may be because the available measure is rather crude. Providers are evidently at greater risk of market exit in cases where they concentrate on Business/IT provision or general provision in contrast to specific specialisms. Providers based in London-by far the most common location-also have a higher market exit rate than providers located elsewhere.

\footnotetext{
${ }^{4}$ Most providers from recently founded for-profit institutions to long establish charities have an entry at Companies House: the remainder have an entry in the charities register.
} 
Table 1 Percentage and total number providers by status

\begin{tabular}{|c|c|c|}
\hline Variable & $\%$ Market exit & Total $N$ \\
\hline \multicolumn{3}{|l|}{ Legal status } \\
\hline For-profit & 50 & 348 \\
\hline Not-for-profit & 10 & 216 \\
\hline \multicolumn{3}{|l|}{ Age of institution } \\
\hline Less than 10 years & 72 & 188 \\
\hline 10 to 19 years & 32 & 130 \\
\hline 20 to 35 years & 13 & 109 \\
\hline Over 35 five & 4 & 137 \\
\hline \multicolumn{3}{|l|}{ Size of institution } \\
\hline Less than 100 students & 37 & 183 \\
\hline 100 or more students & 30 & 284 \\
\hline Missing & 44 & 97 \\
\hline \multicolumn{3}{|l|}{ Subjects taught } \\
\hline Business/IT specialist & 52 & 147 \\
\hline Other specialist & 12 & 257 \\
\hline Non-specialist & 61 & 129 \\
\hline Missing & 29 & 31 \\
\hline \multicolumn{3}{|l|}{ Location of institution } \\
\hline London & 29 & 303 \\
\hline England excl. London & 30 & 232 \\
\hline Scotland & 22 & 18 \\
\hline Wales & 14 & 7 \\
\hline Northern Ireland & 0 & 4 \\
\hline \multicolumn{3}{|l|}{ Course designation } \\
\hline Course designation & 10 & 135 \\
\hline No course designation & 42 & 429 \\
\hline \multicolumn{3}{|l|}{ Tier 4} \\
\hline No Tier 4 issues & 30 & 513 \\
\hline Tier 4 revoked & 84 & 51 \\
\hline \multicolumn{3}{|l|}{ QAA review } \\
\hline QAA review & 40 & 210 \\
\hline No QAA review & 42 & 354 \\
\hline
\end{tabular}

The figures presented in Table 1 also indicate that the regulation-related risk factors of not having course designation and having had a Tier 4 licence revoked, are associated with the likelihood of market exit.

Table 2 presents the findings of a binary logistic regression analysis of the independent effects of provider characteristics and regulation-related risk factors on the likelihood of market exit. In combination, taking the pseudo r-squared value, the independent variables included in the model explain almost $60 \%$ of the variance in the dependent variable, market exit. Furthermore, according to the Wald chi-square values, each of the independent variables, with the exception of size of institution, are independently associated with the likelihood of provider discontinuity.

The expected beta values express the odds ratio for each predictor: that is, the relative chance of the outcome, market exit, occurring under two different conditions. The findings indicate that more recently founded providers are particularly vulnerable to market exit. The odds ratio indicates that new providers are 21 times more likely to fail than those established for 35 years or more. Providers aged 11 to 20 years old were also found to be five times more likely to fail than providers aged thirty-five plus.

The odds ratios tend to be smaller but still substantial in the case of other provider characteristics. For-profit enterprises were three times more likely to fold than not-for- 
Table 2 Predictors of market exit (logit analysis): $N=564$.

\begin{tabular}{|c|c|c|c|c|}
\hline Variable & $B$ & SE & Wald & $\operatorname{Exp}(B)$ \\
\hline \multicolumn{5}{|c|}{ Legal status (reference: not-for-profit) } \\
\hline For-profit institution & $1.08 * *$ & 0.33 & 10.71 & 2.94 \\
\hline \multicolumn{5}{|l|}{ Age (reference: over 35 years) } \\
\hline 10 years or less & $3.04 * * *$ & 0.52 & 34.45 & 21.00 \\
\hline 11 to 20 years & $1.53 * *$ & 0.53 & 8.25 & 4.63 \\
\hline 21 to 35 years & 0.86 & 0.57 & 2.27 & 2.35 \\
\hline \multicolumn{5}{|c|}{ Subjects taught (reference: specialist) } \\
\hline Business/IT & $0.87 * *$ & 0.34 & 6.78 & 2.40 \\
\hline Non-specialist & $1.22 * * *$ & 0.36 & 11.63 & 3.40 \\
\hline Missing & 0.83 & 0.54 & 2.41 & 2.30 \\
\hline \multicolumn{5}{|c|}{ Number of students (reference: $100+$ ) } \\
\hline Under 100 students & -0.10 & 0.30 & 0.10 & 0.91 \\
\hline Missing & -0.12 & 0.36 & 0.11 & 0.89 \\
\hline \multicolumn{5}{|c|}{ Location (reference: England excl. London) } \\
\hline Scotland & -1.31 & 0.91 & 0.42 & 0.56 \\
\hline Wales & -1.32 & 1.30 & 1.01 & 0.27 \\
\hline Northern Ireland & -17.03 & 19,558 & 0.00 & 0.00 \\
\hline London & $0.66^{*}$ & 0.27 & 6.03 & 1.94 \\
\hline \multicolumn{5}{|c|}{ QAA Review (reference: QAA review) } \\
\hline No QAA Review & $0.87 * *$ & 0.30 & 8.46 & 2.39 \\
\hline \multicolumn{5}{|c|}{ Course designation (reference: designation) } \\
\hline No Course Designation & $1.03 * *$ & 0.39 & 7.23 & 2.81 \\
\hline \multicolumn{5}{|c|}{ Tier 4 (reference: No removal of Tier 4 licence) } \\
\hline Removal of Tier 4 licence & $1.22 * *$ & 0.47 & 6.71 & 3.40 \\
\hline Constant & $-5.72 * * *$ & 0.66 & 74.15 & 0.01 \\
\hline
\end{tabular}

Nagelkerke pseudo r-square, 0.57

Chi-square, $302.60(\mathrm{df}=16)^{* * * *}$

-2 LL, 424.71

$*=p<.05 ; * *=p<.01, * * *=p<.001$

profits; while providers specializing in business or IT provision and those with no subject specialism were 2.4 and 3.4 times more likely to close, respectively, compared with providers specializing in areas other than business/IT. Providers located in London were twice as likely to fold as those located in the rest of England, although no differences were observed between England (excluding London) and the rest of the UK.

In terms of regulation-related risk factors, each of these were found to have net effects on the likelihood of market exit. Providers without course designation providing access to governmentbacked student loans were 2.8 times more likely to fold than providers with course designation. Removal of a Tier 4 licence to sponsor international students rendered the institution approximately three and a half times more likely to experience market exit than institutions that either had never held a Tier 4 licence or held one but had not had it revoked. The absence of a QAA review also rendered providers almost two and a half times more likely to exit the market.

\section{Conclusion}

Examining the incidence of market exit in the private sector is informative about the sector itself, which, due to a paucity of data has hitherto been underresearched. There are several risk factors unique to the private sector, or which are felt more acutely, than is the case for public 
providers. Market exit in the private sector also provides insight into the shape it is likely to take should it become a feature of the public higher education sector.

A provider's early years of operation, as they attempt to establish themselves, are critical with respect to market exit. Public providers have existed within the framework of HEFCE, or its national equivalents and previously the UGC, but private providers have never had this protection. Our analysis clearly indicates the particular vulnerability of recently founded providers, which is also characteristic of a more general trend: some $46 \%$ of UK start-ups fail within the first 3 years (Nilsson 2017). The same trend has been observed in the US; while two thirds of start-ups are still around after 2 years, only half survive at least 4 years (Lussier and Halabi 2010).

There are clear examples of the effects of sharpened competition increasing the rate of market exit. Location in London was associated with a greater likelihood of failure, at least compared with the rest of England. This is likely to be due in part to the high proportion of private providers located in the capital competing over the same pool of potential students. The numbers of private providers located in the UK outside of England in 2014 was remarkably small. Again, these data for HE providers are consistent with the broader picture for private enterprises generally. Data for 2013 indicated that business start-ups generally were more likely to fail in London than elsewhere: only $50.1 \%$ of London-located companies formed in 2013 endured for 3 years that is 3.6 percentage points below the national average (Nilsson 2017).

Non-specialist and institutions specializing in Business/IT compared with (other) specialist institutions were also more likely to fail. Again, this is likely to be linked to the densely crowded market, with data for 2017 indicating that a considerable 53\% of all private providers in the UK offer some kind of business or administration qualification (although not all exclusively) (Hunt and Boliver 2019). Further, there is no shortage of such qualifications: the Office of Qualifications and Examinations Regulation recognizes 365 of them at level four or above. Data from HESA indicates that $45 \%(26,355)$ of students on designated courses at private providers were enrolled on business \& administrative courses, far greater than the $14 \%$ in the public sector. This subject, cheap to establish and run, and popular with students, tends to account for much of the specialization found in the for-profit sector.

Due to data limitations, it was impossible to investigate providers' modes of delivery, and so, any potential difference in failure rates between those offering classroom tuition and those offering online courses requires further investigation. Future research might also consider other factors not present in our data, such as information about the student body or faculty, which might dispose a provider towards market exit.

The data did however allow us to examine risks specific to the private sector and those that are felt more acutely included the likelihood of having Tier 4 status removed. This was heightened from 2010 onwards during the government-orchestrated pursuit of "bogus colleges". The removal of Tier 4 licences was not occurring randomly across the private HE sector but seems to have been targeted at those institutions that lacked a distinctive specialization or character: these institutions were likely to have been under greatest pressure or suspicion of being conduits for economic migrants posing as students to access the UK by immigration authorities and the home office.

Absence of a QAA review was also related to market exit. Despite there being risks associate with a QAA review, namely, negative evaluation of provision and the administrative repercussions, even a failed inspection would indicate inclusion or incorporation of a provider in a wider system, and failure is frequently mitigated by the opportunity for directed improvement and re-inspection. This highlights an important intra-sector distinction between 
institutions subject to external oversight and those excluded from any oversight, with the latter more likely to exit the market.

QAA reviews are also instrumental in determining course designation, financial reliability being a necessary condition. Consequently, risky institutions are less likely to receive course designation placing them at greater risk of failure.

Market exit becomes more likely with an absence of barriers to market entry-where these do exist market exit is significantly reduced. This lack of restrictions applies to some not-forprofit companies, but, acting as a form of financial ballast to the not-for-profit providers, are the 153 listed charities. Charities are obliged to demonstrate a far greater degree of potential reliability than a standard start-up. Registering as a charity entails an element of oversight regulation, although institutional rather than educational (Charity Commission 2015). Charities entering the market are more likely to be surer-founded institutions than non-charitable educational providers. Additionally, charities enjoy some tax and VAT relief; this, combined with more severe barriers to entry could render them as more durable institutions.

The pressures associated with market exit faced by the private sector are either unique, such as absence of course designation, or shared but more acutely experienced than in the public sector. Yet the government's ideological commitment to competition within the HE sector and playing out its consequences mean at least some of the pressures associated with market exit will be increased on the public HE sector. Parallels can also be drawn between the private nonspecialist and business/IT delivering providers, particularly the more recent for-profit providers and newer public providers with diminished but indistinguishable levels of prestige, or status, lower entry tariffs, and identical course fees offering a similar array of subjects. These effectively replicate the crowded market for students found in the private sector.

A number of public universities currently stand as possible candidates for failure. Their situation is likely to be further imperilled by uncapped recruitment numbers, with students gravitating to higher profile institutions, and a collapse in the demand for part-time study, so reducing available income for providers in the lower reaches of the public sector (Fazackerley 2017, 2018). But it is falling prey to financial mismanagement or overly optimistic borrowing that is likely to capsize a public provider into failure. HEFCE had the power to block major borrowing by HE institutions, to prohibit more than three successive years of deficits and to offer financial support. The OfS, lacking significant financial resources, instead is to rely on the threat of market exit to instil a sense of financial prudence.

The drive to increase competition in English higher education and promote alternative providers has resulted in not just the creation of the OfS but a new regulatory regime being imposed on English higher education. This places public and private providers under the same framework for the first time. This is likely to force the logics of the two sectors, or at least of the principle players in both, to converge, as public providers face the untempered consequences of competition, becoming yet more market orientated, and private providers, being allowed access to public funds in terms of research and teaching grants, may develop a sense, or a greater sense, of public good. Such a shift can be accounted for in terms of an institutional field approach, which can be usefully applied to higher education as a way of accounting for difference and convergence within a single field.

Market exit, as exemplified in the government's drive against "bogus colleges" has not occurred without collateral damage: numerous students were suddenly left without the prospect of completing the education they paid for in advance (Shepherd 2012). Preventing such a situation in publicly funded institutions has now become the governing body's principle, if not the sole objective when faced with a collapsing provider. Yet, the much vaunted "student 
protection plan" found in both the private and public sector has faced criticism: it has been described as being lightweight, likely to be swept aside in the midst of any political crisis triggered by the collapse of a public provider (Hillman 2018). More generally, student protection plans may be rendered inoperable should a provider go into administration and remain there, as the administrator is charged with running the troubled provider but does so specifically in the interests of any creditors, not its students (Boyd and Kernohan 2018).

The phenomena of market exit in UK higher education has been confined to the private higher education sector to date, and within the private sector market exit is concentrated in areas of provision involving a greater degree of competition and diminished resources. Yet in the public sector, the fate of a struggling public university is likely to be determined not just by market forces but by the presiding authorities' tolerance for the impact and consequences of a public university ceasing to exist.

Funding information The research for this paper was undertaken with the support of the Economic and Social Research Council (UK), the Office for Students (UK) and Research England (UK) (grant reference ES/M010082/ 1), the Centre for Global Higher Education (CGHE), and UCL Institute of Education, London.

Open Access This article is licensed under a Creative Commons Attribution 4.0 International License, which permits use, sharing, adaptation, distribution and reproduction in any medium or format, as long as you give appropriate credit to the original author(s) and the source, provide a link to the Creative Commons licence, and indicate if changes were made. The images or other third party material in this article are included in the article's Creative Commons licence, unless indicated otherwise in a credit line to the material. If material is not included in the article's Creative Commons licence and your intended use is not permitted by statutory regulation or exceeds the permitted use, you will need to obtain permission directly from the copyright holder. To view a copy of this licence, visit http://creativecommons.org/licenses/by/4.0/.

\section{References}

Angulo, A. J. (2016). Diploma Mills. Baltimore, Maryland: Johns Hopkins University.

Bernasconi, A. (2007). Are there research universities in Chile. In P. G. Altbach \& J. Balán (Eds.), World Class Worldwide: Transforming Research Universities in Asia and Latin America (pp. 234-259). Baltimore, MD: Johns Hopkins University press.

BIS. (2016). Success as a knowledge economy: Teaching excellence, social mobility and student choice. Retrieved August 17, 2018 from BIS website: https://www.gov.uk/government/publications/highereducation-success-as-a-knowledge-economy-white-paper

Blagg, K, \& Blom, E. (2018). Evaluating the Return on Investment in Higher Education: An Assessment of Individual- and State-Level Returns. Retrieved January 8, 2020 from https://eric.ed.gov/?id=ED592627

Boyd, C, \& Kernohan, D. (2018). What happens when an alternative provider falls into administration? Retrieved August 14, 2018, from Wonkhe website: https://wonkhe.com/blogs/what-happens-when-an-alternativeprovider-falls-into-administration/

Brown, R. (2008). Higher education and the market. Perspectives: Policy and Practice in Higher Education, 12(3), 78-83. https://doi.org/10.1080/13603100802181125.

Charity Commission. (2015). How to register a charity (CC21b). Retrieved July 30, 2019, from GOV.UK website: https://www.gov.uk/guidance/how-to-register-your-charity-cc21b

Coventry University Group. (2019). Coventry University Group to offer support to GSM London students. Retrieved September 16, 2019, from https://www.coventry.ac.uk/news/coventry-university-group-to-offersupport-to-gsm-london-students/

Coyne, D. (2015). We don’t need no education: Kaplan Law School to close in 2016. Retrieved July 19, 2019, from Legal Business website: https://www.legalbusiness.co.uk/blogs/we-dont-need-no-education-kaplanlaw-school-to-close-in-2016/

Deem, R. (1998). "New managerialism" and higher education: The management of performances and cultures in universities in the United Kingdom. International Studies in Sociology of Education, 8(1), 47-70. https://oi. org/10.1080/0962021980020014. 
Evans, G. (2018). Struggling universities will be shut down, not saved - it's not fair for students. The Guardian. Retrieved February 15, 2019 from https://www.theguardian.com/higher-education-network/2018/feb/05 /struggling-universities-will-be-shut-down-not-saved-its-not-fair-for-students

Fazackerley, A. (2017). What would happen if a UK university went bust? The Guardian. Retrieved November 30, 2018 from https://www.theguardian.com/education/2017/feb/07/what-if-uk-university-goes-bust-ucasstudents

Fazackerley, A. (2018). Fears of university closures after removal of safety net. The Guardian. Retrieved November 30, 2018 from https:/www.theguardian.com/education/2018/jan/30/fears-university-closuresoffice-for-students

Ferlie, E., \& Trenholm, S. (2018). Exploring new organisational forms in English higher education: A think piece. Higher Education 77, 229-245. https://doi.org/10.1007/s10734-018-0269-7.

Ferlie, E., Ashburner, L., Fitzgerald, L., \& Pettigrew, A. (1996). The new public Management in Action. Oxford: Oxford University Press.

Ferlie, E., Musselin, C., \& Andresani, G. (2008). The steering of higher education systems: A public management perspective. Higher Education: The International Journal of Higher Education and Educational Planning, 56(3), 325-348. https://doi.org/10.1007/s10734-008-9125-5.

Fielden, J. (2010). The growth of private and for-profit higher education providers in the UK. Universities UK.

Friedman, M. (1955). The role of government in education. In R. A. Solo \& E. E. Agger (Eds.), Economics and the public interest (pp. 123-144). New Jersey: Rutgers University Press.

GOV.UK (2014). Tier 4 Sponsors whose status has appeared as "Revoked" at any time in the period 1 May 2010-7 October 2014. Retrieved January 18, 2019, from https://www.google.com/url?sa=t\&rct=j\&q= \&esrc=s\&source=web\&cd=1\&ved=2ahUKEwj2oI3IkfffAhUH66QKHR-6AUkQFjAAegQIABAC\&url= https $\% 3 \mathrm{~A} \% 2 \mathrm{~F} \% 2 \mathrm{Fwww}$.gov.uk\%2Fgovernment $\% 2$ Fuploads $\% 2$ Fsystem $\% 2$ Fuploads $\% 2$ Fattachment data\%2Ffile\%2F382447\%2F33101.xlsx\&usg=AOvVaw05fWuYUZ6qZJeDmVC4IzZQ.

Grayling, A. C. (2018). Partnership with Northeastern University. Retrieved July 22, 2019, from New College of the Humanities website: https://www.nchlondon.ac.uk/2018/11/14/northeastern-university/

Grove, J. (2018). Heythrop shuts after efforts to counter effect of $9 \mathrm{~K}$ fees fail. Times Higher Education (THE), p. 14.

H.M. Government. (2017). Higher Education and Research Act 2017. Retrieved July 19, 2017, from http:/www. legislation.gov.uk/ukpga/2017/29/contents/enacted/data.htm

Havergal, C. (2016). QAA reviews raise questions over sector expansion plans. Times Higher Education (THE). Retrieved August 18, 2016 from https://www.timeshighereducation.com/news/quality-assurance-agencyreviews-raise-questions-over-sector-expansion-plans

Hillman, N. (2014). A guide to the removal of student number controls (No. 69). Retrieved November 30, 2018 from HEPI website: https://www.google.com/url?sa=t\&rct=j\&q=\&esrc=s\&source=web\&cd=3\&ved=2 ahUKEwj50cq148jjAhWjThUIHbJXAb0QFjACegQIAhAC\&url=https\%3A\%2F\%2Fwww.hepi.ac.uk\%2 Fwp-content $\% 2$ Fuploads $\% 2$ F2014\%2F09\%2FClean-copy-of-SNC-paper.pdf\&usg=AOvVaw 11 mdEZOnQMWKgmtMr3FMZH

Hillman, N. (2018). Ministers are anything but relaxed about university closures. Retrieved February 15, 2019, from Times Higher Education (THE) website: https://www.timeshighereducation.com/opinion/ministers-areanything-relaxed-about-university-closures

Hunt, S. A., \& Boliver, V. (2019). Market exit in UK higher education. CGHE Working Paper.

Infantino (1998). Individualism in modern thought: From Adam Smith to Hayek: Routledge Studies in Social and Political Thought 13. Retrieved January 24, 2020 from https://ucl-new-primo.hosted.exlibrisgroup. $\mathrm{com} /$ primo-explore/openurl?\%3Fsid=oup:obo\&genre=book\&aulast=Infantino \& title=Individualism $\% 20$ in $\% 20$ modern $\% 20$ thought:\%20From\%20Adam $\% 20$ Smith $\% 20$ to $\% 20$ Hayek\&date=1998\&vid=UCL_VU2 \&institution=UCL\&url_ctx_val=\&url_ctx_fmt=null\&isSerivcesPage=true.

Jongbloed, B. (2004). Regulation and competition in higher education. In P. Teixeira, B. Jongbloed, D. dill, \& a. Amaral (Eds.), Markets in Higer Education: Rhetoric or Reality? (pp. 87-111). Kluwer, Dordrecht, The Netherlands. https://doi.org/10.1007/1-4020-2835-0_5.

Kwiek, M. (2013). From system expansion to system contraction. Access to higher education in Poland. Comparative Education Review, 57(3), 553-576.

Kwiek, M. (2016). From privatization (of the expansion era) to De-privatization (of the contraction era): A National Counter-Trend in a global context. In S. Slaughter \& B. J. Taylor (Eds.), Higher Education, Stratification, and Workforce Development (pp. 311-329). Retrieved June 2, 2016 from https://doi. org/10.1007/978-3-319-21512-9

Lussier, R. N., \& Halabi, C. E. (2010). A three-country comparison of the business success versus failure prediction model. Journal of Small Business Management, 48(3), 360-377. https://doi.org/10.1111/j.1540627X.2010.00298.x.

March, J. G., \& Olsen, J. P. (1989). Organizational basis of politics. New York: The Free Press. 
Marginson, S. (2011). Higher education and public good. Higher Education Quarterly, 65(4), 411-433. https://doi.org/10.1111/j.1468-2273.2011.00496.x.

Marginson, S. (2013). The impossibility of capitalist markets in higher education. Journal of Education Policy, 28(3), 353-370. https://doi.org/10.1080/02680939.2012.747109.

May, T. (2011). Foreign student visas: Home Secretary's statement. Retrieved August 30, 2017, from GOV.UK website: https://www.gov.uk/government/speeches/foreign-student-visas-home-secretarys-statement

McClintock, M., \& Ritchie, W. (2003). Capital building and cash flow at the University of Lancaster. In W. David \& P. David (Eds.), Managing crisis (pp. 32-49). Maidenhead: Open University Press.

McGettigan, A. (2013). The great university gamble: Money, markets and the future of higher education. London: Pluto Books.

Mizobata, S., \& Yoshii, M. (2015). Restructuring of the higher educational system in Japan. In J. C. Brada, W. Bienkowski, \& M. Kuboniwa (Eds.), International Perspectives on Financing Higher Education (pp. 2549). Basingstoke: Palgrave Macmillan. https://doi.org/10.1057/9781137549143_3.

Morgan, J. (2018). DfE 'bends over backwards' to help England's biggest for-profit. Retrieved November 27, 2018, from Times Higher Education (THE) website: https://www.timeshighereducation.com/news/dfebends-over-backwards-help-englands-biggest-profit

Morgan, J. (2019). England's biggest for-profit college goes into administration. Retrieved July 31, 2019, from Times Higher Education (THE) website: https://www.timeshighereducation.com/news/englands-biggestprofit-college-goes-administration

Morton, S. (2019). Dagenham university CU London to help students affected by GSM London closure. Barking and Dagenham Post. Retrieved September 16, 2019 from https://www.barkinganddagenhampost.co. uk/news/cu-london-to-help-students-affected-by-gsm-london-closure-1-6220093

Naidoo, R. (2007). The competitive state and the mobilised market: Higher education policy reform in the United Kingdom. Critique Internationale, 39(2), 47-65.

National Audit Office. (2017). Follow-up on alternative higher education providers (No. HC 411; p. 52). National Audit Office.

Newman, M. (2009, June 26). Hefce considered 'nuclear option' over London met. Times Higher Education (THE). Retrieved February 20, 2019 from https://www.timeshighereducation.com/news/hefce-considerednuclear-option-over-london-met/407156.article

Nilsson, P. (2017). London start-ups are most likely to fail. Retrieved July 29, 2019, from financial times website: https://www.ft.com/content/e3c745c4-88d8-11e7-afd2-74b8ecd34d3b

O'Reilly, N., \& Thomas, S. (2018). Adminstrator's progress report (no. AM 10; p. 20). Retrieved February 20, 2019 from https://beta.companieshouse.gov.uk/company/08788270/filing-history/MzIxMjE1MDY5N2 FkaXF6a2N4/document?format=pdf\&download=0

Palfreyman, D., \& Tapper, T. (2016). The marketization of English higher education and the financing of tuition fees. London Review of Education, 14(4), 47-55.

Public Accounts Committee. (2015). Financial support for students at alternative higher education providers [News from Parliament]. Retrieved September 21, 2018, from UK Parliament website: https://www. parliament.uk/business/committees/committees-a-z/commons-select/public-accountscommittee/news/report-financial-support-for-students-at-alternative-higher-education-providers/

QAA. (2017). A brief student guide to Higher Education Review (Alternative Providers). Retrieved October 10, 2019 from https://www.qaa.ac.uk/docs/qaa/guidance/her-ap-mini-guide-17.pdf?sfvrsn=d6a1f881_6

QAA. (2018). The revised UK Quality Code for Higher Education (p. 7). Retrieved October 10, 2019 from UK Standing Committee for Quality Assessment website: https:/www.qaa.ac.uk/docs/qaa/quality-code/reviseduk-quality-code-for-higher-education.pdf?sfvrsn=4c19f781_8

QAA. (2019). Quality in Action. Retrieved October 10, $20 \overline{19}$ from https://www.qaa.ac.uk/docs/qaa/aboutus/quality-in-action_web-17-18.pdf?sfvrsn=74f7c381_10

Santarelli, E., \& Vivarelli, M. (2007). Entrepreneurship and the process of firms' entry, survival and growth. Industrial and Corporate Change, 16(3), 455-488. https://doi.org/10.1093/icc/dtm010.

Scott, W. R. (2010). Higher education in America: An institutional field approach. Reform and innovation in the changing ecology of US higher education: Inaugural strategy session, December, 2-3. Presented at the Stanford, CA. Retrieved January 10, 2020 from https://cepa.stanford.edu/sites/default/files/ScottWRichard. pdf

Shattock, M. (1988). Financial Management in Universities: The lessons from university college, Cardiff. Financial Accountability \& Management, 4(2), 99-112. https://doi.org/10.1111/j.1468-0408.1988.tb00293. $\mathrm{X}$.

Shattock, M. (2008). The change from private to public governance of British higher education: Its consequences for higher education policy making 1980-2006. Higher Education Quarterly, 62(3), 181-203. https://doi. org/10.1111/j.1468-2273.2008.00392.x. 
Shepherd, J. (2012, May 14). Stranded: The students and staff hit by the crackdown on "bogus" colleges. The Guardian. Retrieved November 30, 2018 from https://www.theguardian.com/education/2012/may/14 /students-private-colleges-closures-immigration

Shury, J., Adams, L., Barnes, M., Huntley Hewitt, J., \& Oozeerally, T. (2016). Understanding the market of alternative higher education providers and their students in 2014. Retrieved September 13, 2016 from BIS website: https://www.gov.uk/government/publications/alternative-providers-of-higher-education-the-marketand-students-in-2014

Smith, B., \& Cunningham, V. (2003). Crisis at Cardiff. In D. Palfreyman \& D. Warner (Eds.), Managing crisis (pp. 8-31). Maidenhead: Open University Press.

Stockwell, R. (2016). New providers. In N. Hillman (Ed.), Hepi report: Vol. 81. Response to the higher education green paper (pp. 59-69). London: Higher Education Policy Institute.

Taylor, M. P. (1999). Survival of the fittest? An analysis of self-employment duration in Britain. The Economic Journal, 109(454), 140-155. https://doi.org/10.1111/1468-0297.00422.

Thomas, D. (2012). London met loses highly trusted sponsor status. Retrieved February 20, 2019, from the PIE news website: https://thepienews.com/news/london-met-loses-highly-trusted-sponsors-status/

Vaughan, R. (2018). Struggling university handed $£ 1 \mathrm{~m}$ bailout to stay afloat. Retrieved March 28, 2019, from inews.Co.Uk website: https://inews.co.uk/news/education/struggling-university-handed-bailout/

Williams, G. (1992). An evaluation of new funding mechanisms in British higher education: Some microeconomic and institutional management issues. Higher Education in Europe, 17(1), 65-85. https://doi. org/10.1080/0379772920170105.

Williams, G. (1997). The market route to mass higher education: British experience 1979-1996. Higher Education Policy, 10(3-4), 275-289. https://doi.org/10.1016/S0952-8733(97)00018-4.

Publisher's note Springer Nature remains neutral with regard to jurisdictional claims in published maps and institutional affiliations.

\section{Affiliations}

\section{Stephen A. Hunt ${ }^{1} \cdot$ Vikki Boliver $^{2}$}

1 Department of Education, Practice and Society, UCL Institute of Education, Centre for Global Higher Education, 20 Bedford Way, London WC1H 0AL, UK

2 Department of Sociology, Durham University, 32 Old Elvet, Durham DH1 3HP, UK 